\title{
Mechanisms of larval transport: vertical distribution of bivalve larvae varies with tidal conditions
}

\author{
Antony M. Knights ${ }^{1, *}$, Tasman P. Crowe ${ }^{2}$, Gavin Burnell ${ }^{1}$ \\ ${ }^{1}$ Aquaculture and Fisheries Development Centre, Department of Zoology, Ecology and Plant Science, \\ University College Cork, The Cooperage, Irish Distillers, North Mall, Cork, Ireland \\ ${ }^{2}$ Marine Biodiversity, Ecology \& Evolution, School of Biology and Environmental Science, Science Centre (West), \\ University College Dublin, Belfield, Dublin 4, Ireland
}

\begin{abstract}
Larval transport is a key process in the life-history and population dynamics of many marine species. It is strongly influenced by ocean currents, but the influence of behavioural traits of larvae (e.g. vertical migration) on their advective dispersal is poorly understood. In the absence of field data, predictions of population connectivity are often based on hydrodynamic models and assume that larvae behave as passive particles. Variations in the vertical distribution of early and late stage larvae of Mytilus spp. were investigated in a field study in the Irish Sea, collecting discrete water samples by Niskin sampler at a range of depths at different tidal states and phases at 2 sites and on 2 dates during summer 2005. Larvae were homogenously distributed throughout the water column during flood tide, whereas larvae we more densely aggregated in middle and bottom waters during ebb tide. Highest densities were greatest near the bottom during low flow conditions. Larval size had no effect on the patterns of vertical distribution of larvae in the water column. The relative lack of larvae in the water column during ebb tides compared to flood tides could lead to significant net transport in the direction of flood tides. If this is a widespread phenomenon, models based on the assumption that larvae behave as passive particles are unlikely to predict dispersal distances correctly.
\end{abstract}

KEY WORDS: Bivalve - Mytilus spp. - Larval transport - Vertical distribution - Hydrodynamics · Behaviour · Modelling

Resale or republication not permitted without written consent of the publisher

\section{INTRODUCTION}

The life-cycle of many marine invertebrates involves a pelagic larval stage which may last for days, weeks or months, and may link populations over potentially large spatial and temporal scales (Alexander \& Roughgarden 1996, Cowen et al. 2000). The scale of dispersal is an important component of an organism's life-history and strongly influences population dynamics and evolution (McQuaid \& Phillips 2000, Kritzer \& Sale 2004). Populations can often be modelled as metapopulations (Kritzer \& Sale 2004) comprising a series of distinct sub-populations maintained by dispersal among them. In this framework, migrants can effectively recolonise sites in which the species has recently become extinct
(Hanski \& Gilpin 1991). Development and maintenance of such metapopulations requires larval connectivity among and potentially within sub-populations, with high larval transport likely to reduce the risk of population extinction (den Boer 1981).

Understanding how larvae are exchanged between populations is therefore vital for prediction of population dynamics in the marine environment. It is thought that larvae are able to control their dispersal to some extent by vertical migration in relation to physical or hydrographic features (e.g. stratification by abiotic and biotic factors) (Dobretsov \& Miron 2001), but this process is poorly understood. In shallow coastal seas, larvae have been shown to control the direction of net travel by ascending into the water column at certain states of the 
tide (flood, ebb, high or low water) and descending to the bottom during others (Schultz et al. 2003). However, in the absence of detailed knowledge of behaviour, larvae are considered in most cases to behave as passive particles and their movements are predicted by hydrodynamic models incorporating only the duration of larval life (Roberts 1997). The passive behavioural assumption limits the effectiveness of recruitment estimations, with models often only partially predicting population distribution (Roberts 1997, Cowen et al. 2000, Leis 2002). This simplistic approach to modelling population dynamics could lead to errors in both research and management (Carr \& Reed 1993). It is therefore important to characterise behavioural traits during larval development (i.e. spawning to settlement).

Behaviour during larval development (e.g. vertical migration) has seldom been investigated for marine invertebrates, especially bivalves (Manuel et al. 1996, Maximovich et al. 1996, Dobretsov \& Miron 2001). Research to date suggests that the distribution of larvae is heterogenous, with early stages staying near the water surface prior to settlement followed by movement towards the bottom by late stages to facilitate settlement (Cragg 1980). Abiotic factors (e.g. temperature, tidal cycle, tidal phase, season) and biotic factors (e.g. food availability) are thought to drive vertical migration patterns (Dobretsov \& Miron 2001, BurdettCoutts \& Metaxas 2004). In mesocosms, early veligers $(<200 \mu \mathrm{m})$ of the scallop Placopecten magellanicus show a preference for surface layers over discontinuity layers (e.g. thermocline) (Gallager et al. 1996). However, experiments of this type may miss much of the detail controlling patterns in nature (see den Boer 1981 for review). More specifically, the influence of tidal flow on vertical distribution and behaviour has not been investigated in detail (e.g. Butman et al. 1994, Cáceres-Martinez \& Figueras 1998, Dobretsov \& Miron 2001, Metaxas 2001, Pernet et al. 2003), particularly in highly turbulent systems.

The Irish Sea is a well-mixed water body (Brown et al. 2003) between the east coast of Ireland and the west coast of Britain. It contains large populations of mussels Mytilus spp. which are a suitable model organism for field-based studies of larval vertical distribution. They spawn in late April to late May and larvae develop planktonically for about $4 \mathrm{wk}$ and settle at around $220 \mu \mathrm{m}$. They are abundant and readily identifiable, particularly in the Irish Sea, where there are few other species of bivalves. Two species are thought to occur in the Irish Sea, M. edulis and M. galloprovincialis; however they cannot be distinguished and are thus referred to as Mytilus spp. herein. This paper presents the results of a study to determine whether patterns of distribution of mussel larvae in the water column vary during different conditions of tidal flow.
The study aimed to determine whether (1) larval densities in the water column vary at a range of temporal scales (month, tidal phase, tidal state), (2) vertical distribution of larvae through the water column varies with tidal phase and state, and (3) a greater proportion of late stage $(>210 \mu \mathrm{m})$ larvae occur near the bottom than at other depths, and a greater proportion of early stage $(<210 \mu \mathrm{m})$ larvae occur near the surface than at other depths.

\section{MATERIALS AND METHODS}

Variation in larval density and vertical distribution. Sampling was carried out in the Blackwater region off the coast of County Wexford in the southern Irish Sea (Fig. 1) during May/June and July/August 2005. Spawning in the region typically occurs between midMay and early-June (A. M. Knights unpubl. data). The May/June sampling was selected to coincide with high proportions of early stage larvae $(<210 \mu \mathrm{m})$ and the July/August sampling to coincide with high proportions of near-settlement, late stage juveniles $(>210 \mu \mathrm{m})$. Two $100 \mathrm{~m} \times 100 \mathrm{~m}$ sites (Site 1: $52^{\circ} 19.542^{\prime} \mathrm{N}, \quad 6^{\circ} 15.538 \mathrm{~W}$; Site 2 : $52^{\circ} 20.036^{\prime} \mathrm{N}$, $6^{\circ} 15.344^{\prime} \mathrm{W}$ ) in $25 \mathrm{~m}$ of water within a $4 \mathrm{~km}^{2}$ area were chosen, with the criteria that both sites had similar bottom topography and were composed of slightly gravelly sand. Mean current speeds at the surface and at the seabed in the region vary between $1 \mathrm{~m} \mathrm{~s}^{-1}$ (surface flood), $0.85 \mathrm{~m} \mathrm{~s}^{-1}$ (surface ebb), $0.70 \mathrm{~m} \mathrm{~s}^{-1}$ (bottom

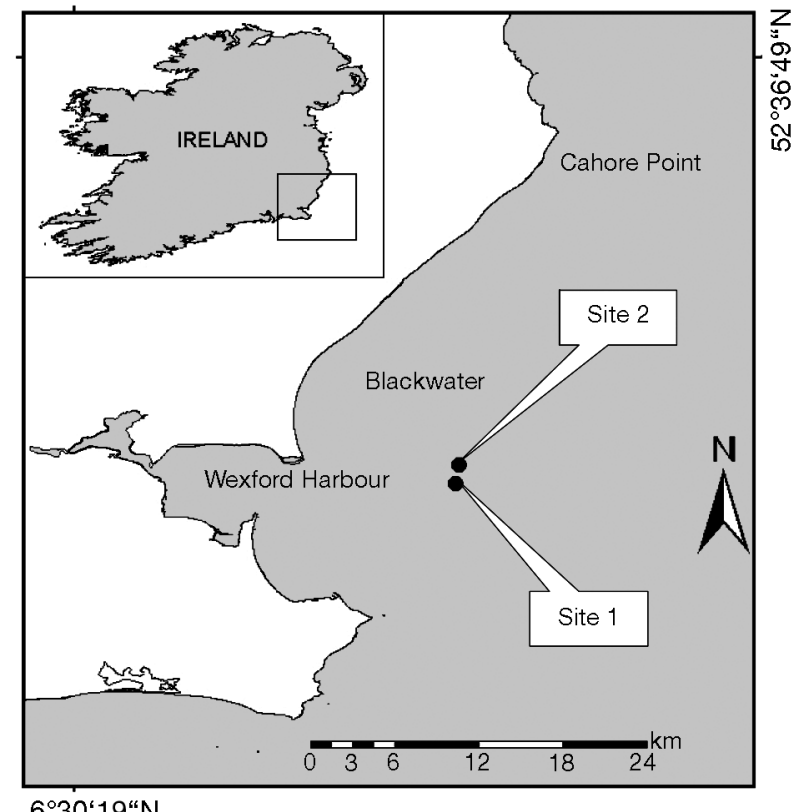

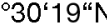

Fig. 1. Blackwater region off the coast of County Wexford in the southern Irish Sea, showing study sites 
flood) and $0.6 \mathrm{~m} \mathrm{~s}^{-1}$ (bottom ebb) (Acoustic Current Doppler Profiler data: Aquafact International pers comm.). Average tidal range varies between +1.2 and $-0.6 \mathrm{~m}$ during spring phases and $\pm 0.3 \mathrm{~m}$ during neap phases (Admiralty Tables 2005).

In each of the 2 periods (May/June and July/August) samples were collected at each site once during spring and once during neap tides and during the 4 tidal states of each tide: (1) flood, (2) ebb, (3) slack high water, (4) slack low water. Tidal oscillations were generated (Admiralty Tables 2005) to identify the phases and states with the most similar tidal amplitudes. The water depth was measured to the nearest $1 \mathrm{~m}$ using a Simrad EQ33 echo sounder, and the water column was divided into 3 equal depth zones: (1) top (0 to $8 \mathrm{~m}$ ), (2) middle (8 to $16 \mathrm{~m})$, (3) bottom (16 to $24 \mathrm{~m}$ ). The Irish Sea is a well-mixed body of water due to strong water currents with no known hydrographic features at particular depths (Brown et al. 2003). Using a vertically mounted, messenger-operated Niskin water sampler collecting a 11 sample, 5 replicate samples were collected from each depth zone at random intervals during the course of each tidal state (considered to be $\pm 1 \mathrm{~h}$ of maximum flood/ebb and $\pm 1 \mathrm{~h}$ high/low water). Samples were preserved in $10 \%$ industrial methylated spirit and the abundance of Mytilus spp. larvae was estimated using the identification keys of Loosanoff et al. (1966), Chanley \& Andrews (1971), de Schweinitz \& Lutz (1976) and Le Pennec (1978).

Larval densities were compared using an orthogonal 5-factor design (1: site [random], 2: time [random], 3: phase [fixed], 4: state [fixed], 5: zone [fixed]) and analysed by analysis of variance (ANOVA) following methods described in Underwood (1997). All computation was carried out using the programme 'GMAV 5' (Underwood \& Chapman 1998). Cochran's C-test was used to test for homogeneity of variances, and in cases of significance $(p<0.05)$, data were square-root $(x+1)$ transformed. In cases where no test was possible, interactive terms that were not significant $(p>0.250)$ were eliminated as per Underwood (1997). For terms which were significant $(\mathrm{p}<0.05)$, Student-Newman-Keuls (SNK) (Newman 1939, Keuls 1952) procedure was used to determine which means differed.

Vertical distribution of larvae of different sizes. Fifteen larvae were randomly subsampled from each set of 5 replicate samples taken from a given depth zone at a given time. Larval shell lengths were measured $( \pm 0.5 \mu \mathrm{m})$ using an Olympus B201 microscope and Optimas Image Analysis software (Media Cybernetics). Larvae were then divided into 2 size classes: $>210 \mu \mathrm{m}$ (late stage) and $<210 \mu \mathrm{m}$ (early stage). This distinction is semi-arbitrary, but is based on the approximate size of a larva at metamorphosis to a pediveliger (Carriker 1961, Lutz 1985). A series of $\chi^{2}$ tests was performed (Fowler et al. 1998) to determine whether late-development larvae were disproportionately abundant nearest the seabed in the bottom depth zone than in other depth zones, and if early development larvae were disproportionately more abundant nearest the surface in the top depth zone compared to the 2 other depth zones, during each tidal flow state (flood, ebb, high and low water). Observed frequencies were compared to expected frequencies generated on the basis of random chance, with a null hypothesis that early or late stage larval were equally likely to be present within each of the 3 depth zones.

\section{RESULTS}

Mytilus spp. larvae were found during both sampling periods, but their numbers were highly variable. The maximum density of larvae in any one sample occurred during the spring tide of May/June, with $22 \mathrm{l}^{-1}$ collected. Samples without larvae were also collected during all time periods, tidal phases and states, highlighting the variability in larval density within the water column.

\section{Variation in density of larvae in relation to time (Ti) tidal phase (Ph) and tidal state (St)}

Overall, there was a $50 \%$ increase in total larval density between May/June and July/August, with an increase in mean density $( \pm \mathrm{SD})$ from $4 \pm 3$ to $6 \pm 4 \mathrm{l}^{-1}$ respectively. During the spring tides of both May/June and July/August, larval densities in the water column were significantly higher during flood tides than all other tidal states. Larval densities of $8 \mathrm{l}^{-1}$ in May/June and $10 \mathrm{l}^{-1}$ in July/August were observed during flood tides, compared to the markedly lower densities during ebb (3 and $\left.5 \mathrm{l}^{-1}\right)$, high (4 and $\left.6 \mathrm{l}^{-1}\right)$ and low tides (4 and $5 \mathrm{l}^{-1}$ ) (Fig. 2, Table 1, Ti $\times \mathrm{Ph} \times \mathrm{St}, \mathrm{p}<0.01$, SNK procedure). During the neap tides of May/June, highest densities were again observed during flood tides ( 7 $\mathrm{l}^{-1}$ ) and lowest densities during ebb tides $\left(3 \mathrm{l}^{-1}\right)$. During slack high and low water periods of neap tides, larval densities did not differ from densities during spring tides (Fig. 2, Table 1, Ti $\times \mathrm{Ph} \times \mathrm{St}$, SNK procedure). During the neap tides of July/August, no differences in larval density were found between tidal states (Fig. 2, Table 1, $\mathrm{Ti} \times \mathrm{Ph} \times \mathrm{St}$, SNK procedure)

Larval densities were highly variable between sites during flood tides, with greater mean densities at Site $2\left(9 \pm 4 \mathrm{l}^{-1}\right)$ than at Site $1\left(5 \pm 2 \mathrm{l}^{-1}\right)$ in May/June. Conversely, in July/August greater densities were found at Site $1\left(10 \pm 31^{-1}\right)$ than at Site $2\left(8 \pm 31^{-1}\right)$ (Fig. 2, Table 1, $\mathrm{Si} \times \mathrm{Ti} \times \mathrm{St}, \mathrm{SNK}$ procedure, $\mathrm{p}<0.01)$. 


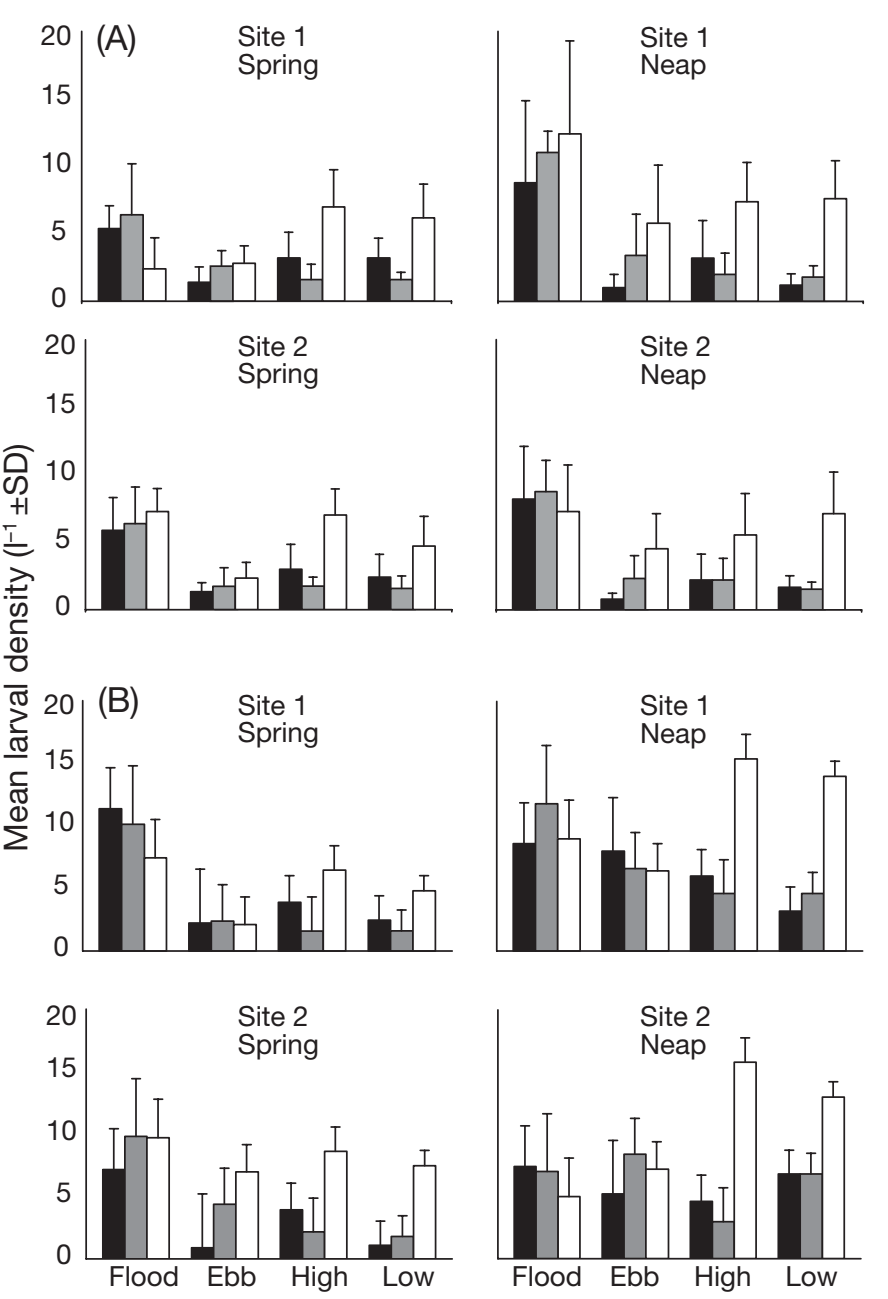

Fig. 2. Mytilus spp. Mean (+SD; $\mathrm{n}=5$ ) density of larvae in 3 depth zones: top (black), middle (grey) and bottom (white). Samples collected over 4 tidal states and during 2 tidal phases at 2 sites during (A) May/June and (B) July/August 2005

\section{Vertical distribution of larvae in relation to tidal state}

Tidal phase had no effect on the distribution of larvae in relation to depth. However, vertical distribution varied considerably with tidal state (Table 1 , St $\times$ Zo, $\mathrm{p}<0.0006)$. At maximum flow rates of flood tides, larvae were distributed homogenously throughout the water column, with densities of $9 \pm 21^{-1}(33 \%)$ at the surface, $10 \pm 4 \mathrm{l}^{-1}(38 \%)$ in the middle depth zone and $8 \pm 21^{-1}(29 \%)$ in the bottom zone (Fig. 2, Table 1, St $\times$ Zo, SNK procedure). During ebb tides, stratification was found between depth zones, with larval densities in the bottom $\left(5 \pm 2 \mathrm{l}^{-1}, 42 \%\right)$ and middle $\left(4 \pm 2 \mathrm{l}^{-1}\right.$, $33 \%$ ) depth zones significantly higher than that within the top zone $\left(3 \pm 11^{-1}, 25 \%\right)$ (Fig. 2, Table 1, St $\times$ Zo, SNK procedure, $\mathrm{p}<0.05$ )
Table 1. Mytilus spp. ANOVA of larval densities in relation to site, time, tidal phase, tidal state and depth zone at Blackwater, County Wexford, in 2005. $\mathrm{n}=5$ replicates. Data are square-root $(x+1)$ transformed; Cochran's $C$-test $=0.0467$, not significant. Values significant at ${ }^{*} \mathrm{p}<0.05$ and ${ }^{* *} \mathrm{p}<0.01$, respectively; - : not tested

\begin{tabular}{|c|c|c|c|c|}
\hline Source & df & MS & $F$ & $\mathrm{p}$ \\
\hline Site (Si) & 1 & 1.40 & 0.81 & 0.533 \\
\hline Time (Ti) & 1 & 22.96 & 13.22 & 0.171 \\
\hline Phase (Ph) & 1 & 6.06 & - & - \\
\hline State (St) & 3 & 15.57 & - & - \\
\hline Zone (Zo) & 2 & 18.24 & - & - \\
\hline $\mathrm{Si} \times \mathrm{Ti}$ & 1 & 1.73 & 7.54 & $0.006^{* *}$ \\
\hline $\mathrm{Si} \times \mathrm{Ph}$ & 1 & 0.80 & 25.63 & 0.124 \\
\hline $\mathrm{Si} \times \mathrm{St}$ & 3 & 0.40 & 0.15 & 0.924 \\
\hline $\mathrm{Si} \times \mathrm{Zo}$ & 2 & 2.59 & 36.11 & $0.027^{*}$ \\
\hline $\mathrm{Ti} \times \mathrm{Ph}$ & 1 & 13.02 & 415.13 & $0.031^{*}$ \\
\hline $\mathrm{Ti} \times \mathrm{St}$ & 3 & 0.31 & 0.11 & 0.946 \\
\hline $\mathrm{Ti} \times \mathrm{Zo}$ & 2 & 0.16 & 2.28 & 0.305 \\
\hline $\mathrm{Ph} \times \mathrm{St}$ & 3 & 2.25 & - & - \\
\hline $\mathrm{Ph} \times \mathrm{Zo}$ & 2 & 0.00 & - & - \\
\hline St $\times$ Zo & 6 & 7.04 & 23.54 & $0.001^{* *}$ \\
\hline $\mathrm{Si} \times \mathrm{Ti} \times \mathrm{Ph}$ & 1 & 0.03 & 0.14 & 0.712 \\
\hline $\mathrm{Si} \times \mathrm{Ti} \times \mathrm{St}$ & 3 & 2.72 & 11.85 & $0.000^{* *}$ \\
\hline $\mathrm{Si} \times \mathrm{Ti} \times \mathrm{Zo}$ & 2 & 0.07 & 0.31 & 0.732 \\
\hline $\mathrm{Si} \times \mathrm{Ph} \times \mathrm{St}$ & 3 & 0.74 & 8.84 & 0.053 \\
\hline $\mathrm{Si} \times \mathrm{Ph} \times \mathrm{Zo}$ & 2 & 1.24 & 3.28 & 0.234 \\
\hline $\mathrm{Si} \times \mathrm{St} \times \mathrm{Zo}^{\mathrm{a}}$ & 6 & 0.27 & 1.09 & 0.460 \\
\hline $\mathrm{Ti} \times \mathrm{Ph} \times \mathrm{St}$ & 3 & 1.87 & 22.30 & $0.015^{*}$ \\
\hline $\mathrm{Ti} \times \mathrm{Ph} \times \mathrm{Zo}$ & 2 & 0.23 & 0.62 & 0.619 \\
\hline $\mathrm{Ti} \times \mathrm{St} \times \mathrm{Zo}$ & 6 & 0.35 & 1.42 & 0.339 \\
\hline $\mathrm{Ph} \times \mathrm{St} \times \mathrm{Zo}$ & 6 & 0.29 & 1.03 & 0.484 \\
\hline $\mathrm{Si} \times \mathrm{Ti} \times \mathrm{Ph} \times \mathrm{St}$ & 3 & 0.08 & 0.36 & 0.779 \\
\hline $\mathrm{Si} \times \mathrm{Ti} \times \mathrm{Ph} \times \mathrm{Zo}$ & 2 & 0.37 & 1.64 & 0.195 \\
\hline $\mathrm{Si} \times \mathrm{Ti} \times \mathrm{St} \times \mathrm{Zo}$ & 6 & 0.25 & 1.09 & 0.369 \\
\hline $\mathrm{Si} \times \mathrm{Ph} \times \mathrm{St} \times \mathrm{Zo}^{\mathrm{a}}$ & 6 & 0.21 & 1.45 & 0.333 \\
\hline $\mathrm{Ti} \times \mathrm{Ph} \times \mathrm{St} \times \mathrm{Zo}$ & 6 & 0.28 & 1.99 & 0.211 \\
\hline $\mathrm{Si} \times \mathrm{Ti} \times \mathrm{Ph} \times \mathrm{St} \times \mathrm{Zo}$ & 6 & 0.14 & 0.63 & 0.706 \\
\hline Residual & 384 & 0.23 & & \\
\hline
\end{tabular}

During periods of minimal tidal flow, larval distribution was highly stratified, with larvae tending to aggregate nearest to the seabed in the bottom depth zone (Fig. 2). During slack high water, stratification was found between all depth zones, with $9 \pm 2 \mathrm{l}^{-1}$ $(60 \%)$ larvae captured in the bottom depth zone, $4 \pm$ $2 \mathrm{l}^{-1}(27 \%)$ in the top depth zone and the remaining $2 \pm 1 \mathrm{l}^{-1}(13 \%)$ in the middle zone (Fig. 2, Table 1, St $\times$ Zo, SNK procedure). During low water slack tide, the highest percentage of larvae was again found in the bottom depth zone: $8 \pm 21^{-1}(57 \%)$ (Fig. 2, Table 1, St $\times$ Zo, SNK procedure). The remaining larvae were distributed evenly between the top and middle depth zones with $3 \pm 1 \mathrm{l}^{-1}(21 \%)$ and $3 \pm 11^{-1}(21 \%)$, respectively (Fig. 2, Table 1, and SNK procedure). 


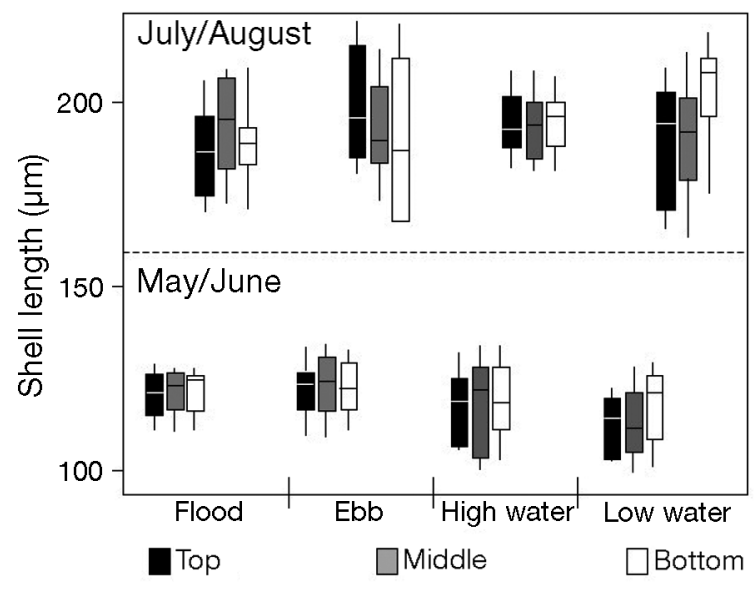

Fig. 3. Mytilus spp. Variation in shell length of larvae collected in May/June and July/August 2005. Larvae were randomly subsampled $(\mathrm{n}=15)$ from a set of 5 replicate samples from each of 3 depth zones: top (0 to $8 \mathrm{~m}$ ), middle (8 to $16 \mathrm{~m}$ ) and bottom (16 to $24 \mathrm{~m}$ ), over 4 tidal states: Flood, Ebb, High water and Low water. Middle lines of boxplots represent medium lengths; hinge lines (end of box) represent $25 \%$ quartiles from the median; whiskers represent 1.5 times the spread beyond the hinge

Table 2. Mytilus spp. Observed frequencies of early $(<210 \mu \mathrm{m})$ and late stage $(>210 \mu \mathrm{m})$ larvae within each depth zone during 4 tidal states, based on 15 individuals sampled from each set of 5 replicate samples per depth per tidal state

\begin{tabular}{|lcccc|}
\hline \multirow{2}{*}{$\begin{array}{l}\text { Depth } \\
\text { zone }\end{array}$} & Flood & Ebb & $\begin{array}{c}\text { Tidal state } \\
\text { High water }\end{array}$ & Low water \\
\hline Early stage & & & & \\
$\quad$ Top & 29 & 24 & 30 & 24 \\
Middle & 27 & 25 & 30 & 25 \\
$\quad$ Bottom & 28 & 20 & 30 & 21 \\
Late stage & & & & \\
Top & 1 & 6 & 0 & 6 \\
Middle & 3 & 5 & 0 & 5 \\
Bottom & 2 & 10 & 0 & 9 \\
\hline
\end{tabular}

\section{Vertical distribution of early and late stage veligers}

The mean larval shell length $( \pm \mathrm{SE})$ increased from $120 \pm 1 \mu \mathrm{m}$ in May/June to $193 \pm 1 \mu \mathrm{m}$ in July/August, with individuals ranging from 99 to $136 \mu \mathrm{m}$ and from 163 to $225 \mu \mathrm{m}$ at each time, respectively. No differences in vertical distribution in relation to depth were observed between early $(<210 \mu \mathrm{m})$ and late $(>210 \mu \mathrm{m})$ stage larvae (Fig. 3, Table 2). $\chi^{2}$ tests of larval size frequency within each depth zone revealed that larvae of different sizes were homogenously distributed throughout the water column. Early stage larvae were evenly distributed throughout the water column during all tidal states (Table 2), whereas late stage larvae were only homogenously distributed during the ebb and low water states (Fig. 3, Table 2). During flood and high water states insufficient late stage larvae were captured to enable an analysis to be performed.

\section{DISCUSSION}

Pedrotti \& Fenaux (1992) described 2 modes of larval dispersal: (1) larvae may remain within a water parcel overlying the adult habitat and subjected to bottom currents, or (2) larvae may be introduced into a different water layer by current advection, and be more greatly influenced by wind-driven transport. In the present study the density of mussel larvae in the water column of the Irish Sea varied depending on tidal state. Maximum densities of larvae were captured during flood tides of both spring and neap tidal phases, whereas minimum densities were found during ebb tides. Regardless of the cause of this pattern, in the Irish Sea it would result in the net northward movement of larvae because the flood tide flows strongly northwards. These larvae would therefore be transported over greater distances in that direction (Roegner 2000, Schultz et al. 2003). The most likely explanation for the lack of larvae in our samples during ebb tides is that they were so closely associated with the seabed (samples collected in the bottom zone were at least $1 \mathrm{~m}$ above the seabed). This may indicate that larvae actively avoid transport during ebb tides. In contrast, the increased larval densities during flood periods may indicate an active process of resuspension to facilitate transport during flood tides. The only other possible explanations are some artifact of the sampling process that acts on ebb or flood tides but not both, or variations in actual abundance over both timescales. Neither of these is very likely. Given the limited swimming speeds of pelagic larval stages (e.g. $3 \mathrm{~cm} \mathrm{~s}^{-1}$ for striped bass Morone saxatilis [Meng 1993] and $0.25 \mathrm{~cm}$ $\mathrm{s}^{-1}$ for veligers of Crepidula fornicata [Hilbish et al. 1999]), Kingsford et al. (2002) argued that larvae must control their exposure to currents by partial navigation in order to control their distance and direction of dispersal. Such a mechanism may underlie the patterns documented in the present study.

The vertical distribution of planktonic larvae of Mytilus spp. within the Irish Sea was also highly dependent on tidal conditions, with larval abundance in different depth zones being strongly influenced by water flow characteristics. During slack water in both sampling periods, larvae were predominantly found within the bottom depth zone, with minimum numbers in the top and middle zones. It is not clear whether the aggregation of larvae within the bottom zone is an active or a passive process. It would certainly be consistent with passive sinking, although gravitational 
sinking rates were not investigated. However, the stratification between the top and middle zones during slack high water, with higher densities of individuals in the top depth zone than in the middle depth zone, suggests some active buoyancy control. Active buoyancy control using mucus to control vertical position has been shown in both adult (Martel \& Chia 1991) and larval (Nozais et al. 1997) stages of other organisms, although the ability of larvae to control their depth within a turbulent system is thought to be greatly limited (Roegner 2000). Larval stratification may result in either wide-scale dispersal, with larvae within the top water zone more susceptible to fast-moving surface currents capable of dispersing larvae great distances (Roegner 2000), or limited dispersal, with larvae within the bottom water zones (closer to the seabed) subjected to slower-moving bottom currents.

Aggregation of Mytilus spp. in the bottom zone may also increase substrate contact and facilitate settlement. If aggregation in the bottom zone is a prelude to settlement, one may expect larger larvae to be prevalent at that depth. Comparisons of larval shell lengths within each depth zone, however, indicated that larvae of different sizes were generally distributed similarly between the 3 depth zones regardless of tidal state. Earlier work on larval distribution had suggested that Mytilus spp. larvae exhibit 'preference' for surface waters during early veliger stages prior to descending into deeper waters close to settlement (Dobretsov \& Miron 2001). Little is known about the ability of early veliger larvae to remain affixed to a substrate prior to development of the attachment apparatus. However, areas of dynamic substrate have been shown to cause involuntary resuspension in clam and cockle larvae (Bouma et al. 2001). The risk of resuspension is compounded if both high turbulence and reduced substrate contact occur simultaneously, and therefore higher densities during high flow periods are unsurprising. As a result, the dispersal of larvae, especially during flood tides is likely to occur over larger areas due to increased susceptibility to surface currents and wind-driven dispersal, with larvae behaving passively during high flow conditions.

Increased abundances in July/August correspond to the reproductive development of local and regional populations of Mytilus spp., with individuals typically spawning in the western Irish Sea from early May to late June (A. M. Knights unpubl. data). Shell length measurements also showed that the variation in larval size in May/June was small, as would be expected shortly after initiation of spawning. The second sampling period (July/August) occurred after all populations had completed spawning. The 'trickling' or nonsynchronous spawning contributions from multiple local and regional populations (Cowen et al. 2000, Kinlan \& Gaines 2003) which supply the larval pool may account for the increased abundances from May/June to July/August. The larger variation in shell lengths during July/August would also indicate 'tricklespawning', with variations in local population synchrony resulting in the simultaneous presence of small and large veligers within the water column. In fact, during the flood and slack high water periods few late stage larvae were captured. In slack high water periods, late stage larvae may have settled onto the seabed in an attempt to attach to a favourable substrate. During the flood tides, the lack of late stage larvae is surprising considering the increased abundances of larvae observed during this tidal state and previous suggestions of buoyancy control enabling transport during flood periods. It may be that, at this late stage, larvae are so closely associated with the bottom that they are not sampled, even when samples are collected within a few metres of the substrate (Crimaldi et al. 2002).

The influence of flow on larval settlement and motility has previously been investigated, primarily within artificial mesocosm environments using velocities up to 1 order of magnitude lower than those observed in the southern Irish Sea (Butman et al. 1994, Metaxas 2001, Pernet et al. 2003). Such work has suggested that Mytilus spp. larvae are unable to overcome flow rates in excess of $>40 \mathrm{l} \mathrm{h}^{-1}$, with larvae acting as passive particles and displaying reduced settlement success (Pernet et al. 2003). The high tidal flow rates in the Irish Sea were associated with less stratification of larvae within the water column than in low flow tidal states. In highly turbulent systems, tidal flow rate appears to overcome any limited ability to control position within the water column. An active movement toward the surface may facilitate transport over greater spatial scales (Roegner 2000). Stratification during ebb tides of increased larval densities in the bottom depth zone and decreased larval densities in the top zone would reduce larval susceptibility to Eckman transport and limit dispersal distance, thus allowing retention within an environment (Roegner 2000, Crimaldi et al. 2002).

The present study has also shown increased densities of larvae in the water column during flood tides and reduced densities during ebb tides. Simplistic models that utilise such assumptions could over- or underestimate dispersal distances, and predictions based solely on water circulation are likely to be inaccurate (Leis 2002). Although it is not clear whether larval transfer from depth zone to depth zone is an active or passive process, the results of this study demonstrate that flow-related stratification does exist. Regardless of the mechanism, it is likely to be influential in larval transport and population dynamics. The assumption of passive larval drift (Roberts 1997) used in many fishery assessment models is therefore potentially misleading. 
Acknowledgements. We thank B. Gaynor and J. O'Toole for all their help during sampling on board their vessels. Many thanks to Ms. M. Ferns and Bord Iscaigh Mhara (BIM) for all logistical support and to L. Firth, M. O'Toole and M. Sala for their help in sample collection and processing. Many thanks also to S. Mariani, S. Irwin, H. Gurney-Smith and 2 anonymous reviewers for their comments on the manuscript. The study was funded by a Marine Institute Strategic RTDI Grant (ST02/03).

\section{LITERATURE CITED}

Admiralty Tables (2005) UK Home Office, Taunton, Somerset Alexander SE, Roughgarden J (1996) Larval transport and population dynamics of intertidal barnacles: a coupled benthic/oceanic model. Ecol Monogr 66:259-275

Bouma H, Duiker JMC, de Vries PP, Herman PMJ, Wolff WJ (2001) Spatial pattern of early recruitment of Malcoma balthica (L.) and Cerastoderma edule (L.) in relation to sediment dynamics on a highly dynamic intertidal sandflat. J Sea Res 45:79-93

Brown J, Carrillo L, Fernand L, Horsburgh KJ, Hill AE, Young EF, Medler KJ (2003) Observations of the physical structure and seasonal jet-like circulation of the Celtic Sea and St. George's Channel of the Irish Sea. Cont Shelf Res 23: 533-561

Burdett-Coutts VA, Metaxas A (2004) The effect of the quality of food patches on larval vertical distribution of the sea urchins Lytechinus variegatus (Lamarck) and Strongylocentrus droebachiensis (Mueller). J Exp Mar Biol Ecol 308:221-236

Butman CA, Frechette M, Geyer WR, Starczak VR (1994) Flume experiments on food supply to the blue mussel Mytilus edulis L. as a function of boundary layer flow. Limnol Oceanogr 39:1755-1768

Cáceres-Martinez J, Figueras A (1998) Distribution and abundance of mussel (Mytilus galloprovincialis Lmk.) larvae and post-larvae in the Ria de Vigo (NW Spain). J Exp Mar Biol Ecol 229:277-287

Carr MH, Reed DC (1993) Conceptual issues relevant to marine harvest refuges - examples from temperate reef fishes. Can J Fish Aquat Sci 50:2019-2028

Carriker MR (1961) Interrelation of functional morphology, behaviour, and autecology in early stages of the bivalve Mercenaria mercenaria. J Elisha Mitchell Sci Soc 77: 168-241

Chanley P, Andrews JD (1971) Aids for identification of bivalve larvae of Virginia. Malacologia 11:45-119

Cowen RK, Lwiza KMM, Sponaugle S, Paris CB, Olson DB (2000) Connectivity of marine populations: open or closed? Science 287:857-859

Cragg SM (1980) Swimming behaviour of the larvae of Pecten maximus L. (Bivalvia). J Exp Mar Biol Ecol 93:11-45

Crimaldi J, Thompson J, Rosman J, Lowe R, Koseff J (2002) Hydrodynamics of larval settlement: the influence of turbulent stress events at potential recruitment sites. Limnol Oceanogr 47:1137-1151

den Boer PJ (1981) On the survival of populations in a heterogenous and variable environment. Oecologia 50:39-53

de Schweinitz EH, Lutz RA (1976) Larval development of the northern horse mussel Modiolus modiolus (L.), including a comparison with the larvae of Mytilus edulis L. as an aid in planktonic identification. Biol Bull (Woods Hole) 150: 348-360

Dobretsov SV, Miron G (2001) Larval and post-larval vertical distribution of the mussel Mytilus edulis in the White Sea. Mar Ecol Prog Ser 218:179-187
Fowler J, Cohen L, Jarvis P (1998) Practical statistics for field biology, 2nd edn. John Wiley \& Sons, Chichester

Gallager SM, Manuel JL, Manning DA, O'Dor RK (1996) Ontogenetic changes in the vertical distribution of giant scallop larvae, Placopecten megellanicus, in $9 \mathrm{~m}$ deep mesocosms as a function of light, food, temperature stratification. Mar Biol 124:679-692

Hanski I, Gilpin M (1991) Metapopulation dynamics - brief history and conceptual domain. Biol J Linn Soc 42:3-16

Hilbish TJ, Sasada K, Eyster LS, Pechenik JA (1999) Relationship between rates of swimming and growth in veliger larvae: genetic variance and covariance. J Exp Mar Biol Ecol 239:183-193

Keuls M (1952) The use of studentized range in connection with an analysis of variance. Euphytica 1:112-122

Kingsford MJ, Leis JM, Shanks AL, Lindeman KC, Morgan SG, Pineda J (2002) Sensory environments, larval abilities and local self-recruitment. Bull Mar Sci (Suppl S) 70: 309-340

Kinlan BP, Gaines SD (2003) Propagule dispersal in marine and terrestrial environments: a community perspective. Ecology 84:2007-2020

Kritzer JP, Sale PF (2004) Metapopulation ecology in the sea: from Levins' model to marine ecology and fisheries science. Fish Fish 5:131-140

Leis JM (2002) Pacific coral-reef fishes: the implications of behaviour and ecology of larvae for biodiversity and conservation, and a reassessment of the open population paradigm. Environ Biol Fish 65:199-208

Le Pennec M (1978) Genese de la coquille larvaire et postlarvaire chez divers bivalves marins. These de Doctorat d'état, Universite de Bretagne Occidentale, Brest

Loosanoff VL, Davis HC, Chanley PE (1966) Dimensions and shapes of larvae of some marine bivalve mollusks. Malacologia 4:351-435

Lutz RA (1985) Identification of bivalve larvae and postlarvae: a review of recent advances. Bull Am Malacol Union Inc (Spec edn) 1:59-78

Manuel JL, Gallager SM, Pearce CM, Manning DA, O'Dor RK (1996) Veligers from different populations of sea scallop Placopecten magellanicus have different vertical migration patterns. Mar Ecol Prog Ser 142:147-163

Martel A, Chia FS (1991) Foot-raising behavior and active participation during the initial phase of post-metamorphic drifting in the gastropod Lacuna spp. Mar Ecol Prog Ser 72:247-254

Maximovich NV, Sukhotin AA, Minichev YS (1996) Longterm dynamics of blue mussel (Mytilus edulis L.) culture settlements (the White Sea). Aquaculture 147:191-204

McQuaid CD, Phillips TE (2000) Limited wind-driven dispersal of intertidal mussel larvae: in situ evidence from the plankton and the spread of the invasive species Mytilus galloprovincialis in South Africa. Mar Ecol Prog Ser 201: 211-220

Meng L (1993) Sustainable swimming speeds of striped bass larvae. Trans Am Fish Soc 122:702-708

Metaxas A (2001) Behaviour in flow: perspectives on the distribution and dispersion of meroplanktonic larvae in the water column. Can J Fish Aquat Sci 58:86-98

Newman D (1939) The distribution of the range of samples from a normal population expressed in terms of an independent estimate of standard deviation. Biometrika 31: $20-30$

Nozais C, Duchene JC, Bhaud M (1997) Control of position in the water column by the larvae of Poecilochaetus serpens (Polychaeta): the importance of mucus secretion. J Exp Mar Biol Ecol 210:91-106 
Pedrotti ML, Fenaux L (1992) Dispersal of echinoderm larvae in a geographical area marked by upwelling (Ligurian Sea, NW Mediterranean). Mar Ecol Prog Ser 86:217-227

Pernet F, Tremblay R, Bourget E (2003) Settlement success, spatial pattern and behavior of mussel larvae Mytilus spp. in experimental 'downwelling' systems of varying velocity and turbulence. Mar Ecol Prog Ser 260:125-140

Roberts CM (1997) Connectivity and management of Caribbean coral reefs. Science 278:1454-1456

Roegner GC (2000) Transport of molluscan larvae through a

Editorial responsibility: Roger Hughes (Contributing Editor), Bangor, UK shallow estuary. J Plankton Res 22:1779-1800

Schultz ET, Lwiza KMM, Fencil MC, Martin JM (2003) Mechanisms promoting upriver transport of larvae of two fish species in the Hudson River estuary. Mar Ecol Prog Ser 251:263-277

Underwood AJ (1997) Experiments in ecology: their logical design and interpretation using analysis of variance. Cambridge University Press, Cambridge

Underwood AJ, Chapman MG (1998) General model analysis of variance, 5 factor (GMAV 5). Institute of Marine Ecology, University of Sydney

Submitted: January 31, 2006; Accepted: April 18, 2006

Proofs received from author(s): October 25, 2006 